\title{
Znaczenie banków w finansowaniu inwestycji rzeczowych w polskim sektorze przedsiębiorstw
}

\section{Wstęp}

W kontekście zachodzących procesów globalizacyjnych i rosnącej konkurencji szczególnego znaczenia nabiera finansowanie działalności rozwojowej przedsiębiorstw. Polskie przedsiębiorstwa stanęły obecnie przed koniecznością sfinansowania wielu przedsięwzięć inwestycyjnych, dysponując ograniczonymi zasobami kapitałowymi. Problematyka badawcza obejmuje finansowanie inwestycji rzeczowych w sektorze przedsiębiorstw w Polsce w perspektywie czasowej od 1995 do 2011 roku. Celem niniejszego opracowania jest identyfikacja struktury finansowania inwestycji rzeczowych $\mathrm{w}$ sektorze przedsiębiorstw w Polsce oraz określenie roli bankowych źródeł finansowania. Dysponując opisem i wyjaśnieniami można wytyczyć kierunek zmian w obszarze finansowania przedsiębiorstw.

\section{Konceptualizacja badań}

Dane wykorzystywane w prowadzonych analizach pochodzą z rachunków narodowych. Europejski System Rachunków Narodowych i Regionalnych (ESA 95) stanowi zgodny międzynarodowy standard metodologiczny i rachunkowy dla szczegółowego opisu gospodarki, jej składowych oraz relacji z innymi gospodarkami [Rozporządzenie Rady (WE) Nr 2223/96, 1.01]. Podstawowy schemat ESA 95 obejmuje dwa główne zestawy tabel, a mianowicie: rachunki sektorów oraz układ przepływów międzygałęziowych i rachunki według rodzajów działalności. 
Rachunki sektorów dostarczają systemowego opisu różnych etapów procesów gospodarczych (według sektorów instytucjonalnych), tj. produkcji, tworzenia dochodów, podziału pierwotnego dochodów, podziału wtórnego dochodów, wykorzystania dochodów oraz akumulacji finansowej i niefinansowej. Rachunki sektorów obejmują również bilanse dla opisu stanów aktywów, pasywów i wartości netto na początek i koniec okresu sprawozdawczego. Układ przepływów międzygałęziowych i rachunki według rodzajów działalności opisują z większą szczegółowością procesy produkcji oraz przepływy towarów i usług [Rozporządzenie Rady (WE) Nr 2223/96, 1.02].

ESA 95 rejestruje przepływy i zasoby w uporządkowanym zestawie rachunków, które opisują cykl ekonomiczny od tworzenia dochodu, poprzez jego podział pierwotny i wtórny, aż do jego końcowej akumulacji w postaci aktywów [Rozporządzenie Rady (WE) Nr 2223/96, 8.01]. Każdy z rachunków przedstawia transakcje, które zostały zbilansowane czy to $\mathrm{z}$ tytułu zastosowanych definicji, czy też z tytułu znaczącego salda przenoszonego na następny rachunek [Rozporządzenie Rady (WE) Nr 2223/96, 8.02]. Rejestrowanie transakcji w układzie wynikającym z analizy życia ekonomicznego dostarcza agregaty niezbędne do badania sytuacji gałęzi gospodarczej, sektora instytucjonalnego czy podsektora lub gospodarki ogółem. Podział rachunków został zaprojektowany w sposób umożliwiający pokazanie najbardziej znaczących informacji ekonomicznych [Rozporządzenie Rady (WE) Nr 2223/96, 8.03]. Rachunki są grupowane w trzech kategoriach, tj. rachunki bieżące, rachunki akumulacji oraz bilanse. Rachunki bieżące dotyczą produkcji, tworzenia i podziału dochodów oraz ich wykorzystania w formie spożycia ostatecznego. Rachunki bieżące pozwalają ostatecznie oszacować oszczędności stanowiące podstawowy czynnik finansowania akumulacji. W rachunkach akumulacji analizie poddane zostają rozmaite składniki zmian aktywów i pasywów różnych jednostek. Umożliwiają one zarejestrowanie zmian wartości netto (różnica między aktywami a pasywami). Bilanse pokazują aktywa i pasywa ogółem różnych jednostek na początek i koniec okresu sprawozdawczego, łącznie z ich wartością netto. Przepływy zarejestrowane na rachunkach akumulacji dla poszczególnych pozycji aktywów i pasywów są widoczne ponownie na rachunku zmian w bilansie [Rozporządzenie Rady (WE) Nr 2223/96, 8.03].

Dane wykorzystane przy szacowaniu struktury finansowania inwestycji rzeczowych sektora przedsiębiorstw pozyskano $\mathrm{z}$ dwóch rachunków wchodzących w skład rachunków akumulacji, tj.: rachunku kapitałowego oraz rachunku finansowego. Rachunek kapitałowy rejestruje nabycie pomniejszone o rozdysponowanie aktywów niefinansowych dokonywane przez jednostki będące rezydentami, a także mierzy zmianę wartości netto wynikającą z oszczędności oraz 
transferów kapitałowych [Rozporządzenie Rady (WE) Nr 2223/96, 8.46]. Dane pozyskane z rachunku kapitałowego umożliwiają określenie zakresu, w jakim nabycie pomniejszone o rozdysponowanie aktywów niefinansowych było finansowane z oszczędności oraz z transferów kapitałowych. Pozycją bilansującą rachunek kapitałowy są wierzytelności netto, które odpowiadają kwocie dostępnej jednostce czy sektorowi na cele finansowania (bezpośrednio lub pośrednio) innych jednostek czy sektorów, albo zadłużenie netto, które odpowiada kwocie, jaką jednostka lub sektor zmuszone są pożyczyć od innych jednostek lub sektorów [Rozporządzenie Rady (WE) Nr 2223/96, 8.47]. Rachunek finansowy rejestruje natomiast, według rodzajów instrumentów finansowych, zmiany aktywów i pasywów finansowych tworzące wierzytelności czy zadłużenie netto [Rozporządzenie Rady (WE) Nr 2223/96, 8.50]. Po swojej lewej stronie pokazuje on nabycie pomniejszone o sprzedaż aktywów finansowych, po prawej - zaciągnięcie zobowiązań pomniejszone o ich spłatę. Pozycją bilansującą ten rachunek jest nabycie netto aktywów finansowych pomniejszone o zaciagnięcie netto zobowiązań, które stanowi wierzytelności netto $(+) /$ zadłużenie netto (-) [Rozporządzenie Rady (WE) Nr 2223/96, 5.10]. Rachunek finansowy jest rachunkiem, który kończy całą kolejność rachunków rejestrujących transakcje. Rachunek ten nie posiada więc pozycji bilansującej, która przenoszona jest do następnego rachunku. Pozycja bilansująca rachunku finansowego jest w systemie rachunków narodowych identyczna z pozycją bilansującą rachunku kapitałowego ${ }^{1}$ [Rozporządzenie Rady (WE) Nr 2223/96, 5.14]. Przyjąć więc można, iż w danym okresie źródła funduszy w sektorze przedsiębiorstw (przychody) są równe ich wykorzystaniu (rozchody). Na podstawie rachunku przepływów funduszy możliwe jest oszacowanie struktury finansowania w sektorze przedsiębiorstw. Część pozyskanych przez przedsiębiorstwa funduszy przeznaczana jest jednak na akumulację finansowych, a nie rzeczowych aktywów. W celu zidentyfikowania źródeł finansowania związanych z inwestycjami rzeczowymi proponuje się, aby od zaciaggniętych pasywów netto (przyrost zobowiązań finansowych) odjać nabytki aktywów finansowych netto (przyrost należności finansowych) (tab. 1). Podejście takie zainicjował Mayer [1988, 1990], a rozpropagowali Corbett i Jenkinson [1996 i 1997]. Mierzy ono strukturę finansowania netto inwestycji rzeczowych. Stosując to podejście, nie znajdzie się oczywiście odpowiedzi na pytanie, jak finansowane są konkretne projekty inwestycyjne, określić jednak będzie można znaczenie różnych źródeł funduszy w finansowaniu

\footnotetext{
${ }^{1} \mathrm{~W}$ praktyce znaleźć jednak można rozbieżności pomiędzy nimi, a to dlatego, że zestawiane są one na podstawie różnych danych statystycznych [Rozporządzenie Rady (WE) Nr 2223/96, 5.14].
} 
Tabela 1

Rachunek przypływu funduszy

\begin{tabular}{|l|l|}
\hline \multicolumn{2}{|c|}{ Metoda „spłaty netto” } \\
\hline \multicolumn{1}{|c|}{ Przychody brutto } & \multicolumn{1}{c|}{ Rozchody brutto } \\
\hline 1. Wewnętrzne & 9. Gotówka i depozyty \\
\hline 2. Pożyczki bankowe & 10. Akcje zakupione \\
\hline 3. Akcje wyemitowane & 11. Obligacje zakupione \\
\hline 4. Obligacje wyemitowane & $\begin{array}{l}\text { 12. Pozostałe kwoty do otrzymania/zapła- } \\
\text { cenia }\end{array}$ \\
\hline 5. Pozostałe kwoty do otrzymania/zapłacenia & 13. Transfery kapitałowe \\
\hline 6. Transfery kapitałowe & 14. Inne \\
\hline 7. Inne & 15. Inwestycje rzeczowe \\
\hline 8. PRZYCHODY OGÓŁEM & 16. ROZCHODY OGÓŁEM \\
\hline \multicolumn{1}{|c|}{ Przychody netto } & \multicolumn{1}{c|}{ Rozchody netto } \\
\hline \multicolumn{2}{|c|}{ Metoda „zbilansowana netto” } \\
\hline Wewnętrzne (1) & \\
\hline Bankowe netto (2-9) & \multicolumn{1}{|c|}{ INWESTYCJE RZECZOWE (15) } \\
\hline Akcje netto (3-10) & \\
\hline Obligacje netto (4-11) & \\
\hline Kredyty handlowe netto (5-12) & \\
\hline Transfery kapitałowe netto (6-13) & Inne netto (7-14) \\
\hline PRZYCHODY NETTO (8-9-10-11-12-13-14) & \\
\hline
\end{tabular}

Uwagi: Wewnętrzne = oszczędności brutto; pożyczki bankowe = pożyczki krótkoterminowe + + długoterminowe; obligacje = papiery wartościowe inne niż akcje; akcje = akcje i inne udziały kapitałowe; pozostałe kwoty do otrzymania/zapłacenia = kredyty handlowe i zaliczki + pozostałe kwoty do otrzymania/zapłacenia poza kredytami handlowymi i zaliczkami; transfery kapitałowe = transfery kapitałowe otrzymane/płacone; inne = rezerwy techniczno-ubezpieczeniowe; gotówka i depozyty = gotówka i depozyty + pożyczki krótkoterminowe + pożyczki długoterminowe; inwestycje rzeczowe $=$ akumulacja $=$ nakłady brutto na środki trwałe + przyrost rzeczowych środków obrotowych + przyrost aktywów o wyjątkowej wartości.

Źródło: [Samborski 2011, s. 160].

inwestycji rzeczowych sektora przedsiębiorstw w określonym przedziale czasu [Samborski 2011, s. 152-160].

W ESA 1995 sektor przedsiębiorstw (sektora spółek niefinansowych) obejmuje jednostki instytucjonalne, w odniesieniu do których transakcje podziału i transakcje finansowe są oddzielone od transakcji dotyczących ich właścicieli oraz, które są producentami rynkowymi i których podstawą działalności jest wytwarzanie towarów i usług niefinansowych [GUS 2000, s. 37; Rozporządze- 
nie Rady (WE) Nr 2223/96, 2.21]. Pojęciem „spółki niefinansowe” określa się wszystkie podmioty uznane za niezależne podmioty prawne, będące producentami rynkowymi i których podstawą działalności jest wytwarzanie towarów i usług niefinansowych [Rozporządzenie Rady (WE) Nr 2223/96, 2.23].

\section{Sektor przedsiębiorstw w Polsce w świetle rachunków narodowych - kluczowe wskaźniki}

Ocena kondycji ekonomicznej i procesów inwestycyjnych w polskim sektorze przedsiębiorstw dokonana zostanie na podstawie kształtowania się wybranych wskaźników makroekonomicznych zaklasyfikowanych przez EUROSTAT jako kluczowe [EUROSTAT 2013]. Są nimi: stopa inwestycji brutto, współczynnik zysku brutto, zwrot brutto z zaangażowanego kapitału (przed opodatkowaniem), współczynnik długu netto do przychodów (po opodatkowaniu), zwrot netto z kapitału własnego (po opodatkowaniu) (tab. 2).

Stopa inwestycji brutto to udział nakładów brutto na środki trwałe w wartości dodanej brutto (wyrażony w procentach). Nakłady brutto na środki trwałe obejmują nabycie środków trwałych przez krajowych producentów, pomniejszone o ich rozdysponowanie, a następnie powiększone o określone wartości wynikające z podniesienia walorów aktywów niewytworzonych, zrealizowane w wyniku działalności produkcyjnej producentów czy jednostek instytucjonalnych w ciagu danego okresu. Środki trwałe stanowią rzeczowe aktywa trwałe lub wartości niematerialne i prawne wytworzone w wyniku procesów produkcji, które same są wykorzystywane w procesie produkcji w sposób powtarzalny lub ciagły przez okres dłuższy niż jeden rok [Rozporządzenie Rady (WE) $\mathrm{Nr} 2223 / 96,3.102]$. Wartość dodana brutto to wartość produktów (wyrobów i usług) wytworzona przez jednostki krajowe rynkowe i nierynkowe pomniejszona o zużycie pośrednie poniesione w związku z jej wytworzeniem [GUS 2013]. Współczynnik ten odnosi więc inwestycje przedsiębiorstw niefinansowych w środki trwałe (budynki, maszyny itp.) do wartości dodanej tworzonej w procesie produkcji. W latach 1995-2010 przeciętny udział nakładów brutto na środki trwałe $\mathrm{w}$ wartości dodanej brutto wyniósł $28 \%$. W tym czasie wyodrębnić więc można dwa okresy, kiedy to stopa inwestycji była znacząco wyższa bądź zbliżona do średniej. Są to lata 1996-2001 oraz 2007-2008. Pierwszy okres cechuje się jednak znacznie wyższym poziomem inwestycji, kiedy to w 2000 roku nakłady brutto na środki trwałe osiagnęły aż 38,2\% wartości dodanej brutto wytworzonej przez sektor przedsiębiorstw. Pamiętać bowiem należy, iż lata 1996-2001 były okresem bardzo intensywnego unowocześniania gospodarki. 
Tabela 2

Sektor przedsiębiorstw w Polsce - kształtowanie się kluczowych wskaźników w latach 1995-2010 [\%]

\begin{tabular}{|c|c|c|c|c|c|}
\hline Lata & $\begin{array}{c}\text { Stopa } \\
\text { inwestycji } \\
\text { brutto }\end{array}$ & $\begin{array}{c}\text { Współczynnik } \\
\text { zysku brutto }\end{array}$ & $\begin{array}{c}\text { Stopa zwrotu brutto } \\
\text { z zaangażowanego } \\
\text { kapitału, przed opo- } \\
\text { datkowaniem }\end{array}$ & $\begin{array}{c}\text { Współczynnik } \\
\text { długu netto do } \\
\text { przychodów, po } \\
\text { opodatkowaniu }\end{array}$ & $\begin{array}{c}\text { Stopa zwrotu } \\
\text { netto z kapitału } \\
\text { własnego, po } \\
\text { opodatkowaniu }\end{array}$ \\
\hline 1995 & 25,0 & 34,7 & 16,9 & - & - \\
\hline 1996 & 29,6 & 31,4 & 17,9 & - & - \\
\hline 1997 & 32,6 & 33,4 & 22,5 & - & - \\
\hline 1998 & 35,4 & 33,1 & 21,0 & - & 4,4 \\
\hline 1999 & 37,5 & 34,2 & 21,7 & 817 & 7,4 \\
\hline 2000 & 38,2 & 36,7 & 23,6 & 622 & 6,2 \\
\hline 2001 & 29,4 & 33,8 & 25,1 & 971 & 5,9 \\
\hline 2002 & 25,2 & 38,0 & 24,5 & 1134 & 8,6 \\
\hline 2003 & 23,8 & 42,1 & 21,6 & 496 & 12,8 \\
\hline 2004 & 22,4 & 47,4 & 25,5 & 193 & 11,4 \\
\hline 2005 & 22,9 & 47,2 & 24,5 & 177 & 11,8 \\
\hline 2006 & 25,0 & 47,1 & 23,1 & 174 & 10,4 \\
\hline 2007 & 27,9 & 47,0 & 21,6 & 207 & 13,0 \\
\hline 2008 & 28,0 & 44,9 & 23,6 & 277 & 16,8 \\
\hline 2009 & 23,7 & 49,2 & 26,1 & 174 & 18,4 \\
\hline 2010 & 21,0 & 47,8 & 26,2 & 153 & \\
\hline
\end{tabular}

Źródło: [EUROSTAT, dostęp: 23 09. 2013].

Współczynnik zysku brutto jest ilorazem nadwyżki operacyjnej brutto i wartości dodanej brutto (wyrażonym w procentach). Nadwyżka operacyjna brutto to ta część wartości dodanej, która stanowi dochód sektora przedsiębiorstw z tytułu prowadzenia działalności produkcyjnej oraz posiadania kapitału [GUS 1996, s. 88]. Ten współczynnik zyskowności pokazuje tę część wartości dodanej powstałej podczas procesu produkcji, która stanowi wynagrodzenie za kapitał. Na podstawie kształtowania się tego wskaźnika można dokonać oceny wyników sektora przedsiębiorstw i jego zdolności do generowania zysku z produkcji, tj. dochodów z kapitału. Poziom tego wskaźnika uzależniony jest od kształtowania się takich czynników, jak: siła robocza, kapitałochłonność branż, wydajność pracy, poziom kosztów pracy [Leythienne, Smokova 2009, s. 2]. W latach 1995-2010 średni udział nadwyżki operacyjnej brutto w wartości dodanej brutto wyniósł 40,5\%. Współczynnik ten ponadprzeciętną wartość osiagną̧ w latach 
2003-2010, co w dużej mierze związane jest ze wzrostem wydajności pracy $\mathrm{w}$ stosunku do poprzedniego okresu.

Stopa zwrotu brutto z zaangażowanego kapitału, przed opodatkowaniem, wyraża udział nadwyżki operacyjnej brutto $\mathrm{w}$ różnicy pomiędzy podstawowymi pasywami i aktywami finansowymi (wyrażony w procentach). Kategoria podstawowe pasywa i aktywa finansowe obejmuje: gotówkę i depozyty, papiery dłużne (poza derywatami finansowymi), pożyczki oraz akcje i inne udziały kapitałowe. Aktywa finansowe to aktywa ekonomiczne obejmujące środki płatnicze, należności finansowe oraz aktywa ekonomiczne bliskie w swej naturze należnościom finansowym [Rozporządzenie Rady (WE) Nr 2223/96, 7.20]. Wszystkie aktywa finansowe w systemie posiadają swoje odpowiedniki w postaci pasywów. Uwaga ta nie dotyczy aktywów finansowych zaklasyfikowanych do kategorii złota monetarnego i Specjalnych Praw Ciagnienia [Rozporządzenie Rady (WE) $\mathrm{Nr} 2223 / 96,7.23]$. Wskaźnik ten jest miarą efektywności alokacji kapitału w gospodarce. W latach 1995-2010 przeciętny udział nadwyżki operacyjnej brutto w pasywach finansowych netto wyniósł $22,8 \%$. W badanym okresie wskaźnik ten utrzymywał się więc na wysokim poziomie, przekraczając w latach 2009, 2010 wartość $26 \%$, co świadczyć może o poprawie efektywności alokacji kapitału w sektorze przedsiębiorstw w Polsce w konsekwencji dekoniunktury w gospodarce światowej.

Współczynnik długu netto do przychodów, po opodatkowaniu, zdefiniować można jako stosunek zadłużenia netto, wyrażonego różnicą pomiędzy głównymi pasywami i aktywami finansowymi, i dochodu przedsiębiorcy netto pomniejszonego o podatki od dochodów i majątku. Innymi słowy współczynnik długu netto do przychodów, po opodatkowaniu, to udział wyrażony w procentach różnicy pomiędzy głównymi pasywami i aktywami finansowymi w dochodzie przedsiębiorcy netto pomniejszonym o podatki od dochodów i majątku. Kategoria główne pasywa i aktywa finansowe obejmuje: gotówkę i depozyty, papiery dłużne (poza derywatami finansowymi), pożyczki. Dochód przedsiębiorcy jest równy nadwyżce operacyjnej lub dochodowi mieszanemu (na stronie przychodów) powiększonej (plus) o dochód z tytułu własności otrzymywany w związku z finansowymi i innymi aktywami należącymi do przedsiębiorstwa (na stronie przychodów) skorygowanej (minus) o odsetki od długów płacone przez przedsiębiorstwo oraz renty gruntowe i czynsze płacone za dzierżawione grunty i inne rzeczowe aktywa niewytworzone (na stronie rozchodów) [Rozporządzenie Rady (WE) Nr 2223/96, 8.28]. Podatki od dochodów, majątku itp. obejmują wszystkie obowiązkowe, bezzwrotne transfery pieniężne lub w naturze, dokonywane okresowo przez jednostki instytucjonalne na rzecz instytucji rządowych i samorządowych oraz zagranicy. Kategoria ta obejmuje również niektóre okresowe podatki niezwiązane ani z dochodem, ani z majątkiem jednostki instytucjonalnej 
[Rozporządzenie Rady (WE) Nr 2223/96, 4.77]. Współczynnik długu netto do przychodów, po opodatkowaniu, wyraża zdolność (bądź jej brak) sektora przedsiębiorstw do pokrycia bieżących zobowiązań z działalności operacyjnej [Hronová, Hindls 2012]. W latach 1999-2010 wartość współczynnika długu netto do przychodów, po opodatkowaniu, znacząco zmalała, z poziomu 817 do $153 \%$, co oznacza poprawę zdolności sektora przedsiębiorstw do pokrywania bieżących zobowiązań z działalności operacyjnej.

Zwrot netto z kapitału własnego, po opodatkowaniu, wyraża udział procentowy dochodu przedsiębiorcy netto pomniejszonego o podatki od dochodu i majątku w akcjach i innych udziałach kapitałowych netto (pasywa i aktywa). Akcje i inne udziały kapitałowe to wszystkie transakcje dokonywane na akcjach i innych udziałach kapitałowych, czyli aktywach finansowych reprezentujących prawa własności do przedsiębiorstw i instytucji finansowych lub spółek ułomnych [Rozporządzenie Rady (WE) Nr 2223/96, 5.86]. W latach 1999-2010 wartość stopy zwrotu netto z kapitału własnego, po opodatkowaniu, wzrosła z 4,4 do $18,4 \%$, co oznacza poprawę efektywności wykorzystania w sektorze przedsiębiorstw kapitału udziałowego.

\section{Struktura finansowania inwestycji rzeczowych w sektorze przedsiębiorstw - rola banków}

W latach 1995-2011 nastapiły znaczące zmiany w strukturze finansowania inwestycji rzeczowych w sektorze przedsiębiorstw działającym w Polsce (tab. 3). W okresie umacniania się gospodarki rynkowej, tj. w latach 1995-2000 poziom finansowania wewnętrznego utrzymywał się na niskim pułapie, w przedziale $48,2-54,7 \%$. W okresie tym istotną rolę w finansowaniu inwestycji rzeczowych odegrały źródła bankowe. Po 2000 roku znacząco wzrósł udział źródeł wewnętrznych w strukturze finansowania inwestycji rzeczowych, przekraczając w latach 2005, 2009, 2010 poziom 100\%. Zmalał natomiast udział źródeł bankowych, który to w latach 2003-2005, 2009-2010 przyjął wartości ujemne.

Zastanawiając się nad przyczynami tych zmian, w pierwszej kolejności warto wziąć pod uwagę strukturę gospodarczą Polski. Zauważyć należy, iż w gospodarce polskiej udział sektora wytwórczego jest znaczący. Banki stanowić powinny więc istotne źródło finansowania inwestycji rzeczowych. Przemysł wytwórczy cechuje bowiem wysoka kapitałochłonność, a liczne aktywa materialne stanowić mogą dobre zabezpieczenie kredytów udzielanych na zakup środków trwałych. Kluczową rolę w gospodarce polskiej odgrywa też sektor MSP, dla którego naturalnym źródłem finansowania zewnętrznego są banki. W latach 1995-2011 
Tabela 3

Struktura finansowania inwestycji rzeczowych w polskim sektorze przedsiębiorstw w latach 1995-2011 [\%]

\begin{tabular}{|l|c|r|r|r|r|r|r|}
\hline Lata & Wewnętrzne & $\begin{array}{c}\text { Bankowe } \\
\text { netto }\end{array}$ & $\begin{array}{c}\text { Akcje } \\
\text { netto }\end{array}$ & $\begin{array}{c}\text { Obligacje } \\
\text { netto }\end{array}$ & $\begin{array}{c}\text { Pozostałe kwoty } \\
\text { do otrzymania/ } \\
\text { /zapłacenia netto }\end{array}$ & $\begin{array}{c}\text { Transfery } \\
\text { kapitałowe } \\
\text { netto }\end{array}$ & $\begin{array}{c}\text { Inne } \\
\text { netto }\end{array}$ \\
\hline 1995 & 54,7 & 30,1 & $-0,1$ & $-4,7$ & 23,2 & 6,9 & $-0,6$ \\
\hline 1996 & 56,6 & 22,6 & 12,6 & 0,0 & 9,1 & 8,3 & $-0,9$ \\
\hline 1997 & 54,7 & 13,7 & 18,2 & $-5,6$ & 30,0 & 5,1 & 0,4 \\
\hline 1998 & 50,0 & 23,4 & 17,8 & 3,2 & 8,4 & 6,3 & $-0,9$ \\
\hline 1999 & 48,2 & 5,9 & 23,1 & 8,1 & 13,9 & 2,3 & $-0,6$ \\
\hline 2000 & 53,8 & 20,7 & $-15,3$ & 4,9 & 34,5 & 1,9 & $-0,9$ \\
\hline 2001 & 63,1 & 8,7 & $-2,8$ & 2,4 & 27,4 & 3,1 & $-1,3$ \\
\hline 2002 & 81,8 & 12,4 & 11,4 & 1,6 & $-9,9$ & 2,3 & $-0,4$ \\
\hline 2003 & 106,6 & $-9,4$ & 30,0 & $-17,4$ & $-15,7$ & 6,8 & $-1,1$ \\
\hline 2004 & 93,8 & $-24,1$ & 36,7 & $-5,8$ & 7,9 & 5,3 & $-1,1$ \\
\hline 2005 & 104,2 & $-8,6$ & 12,5 & 4,6 & $-4,5$ & 5,6 & $-0,2$ \\
\hline 2006 & 88,0 & 13,6 & 26,4 & 2,8 & $-9,9$ & 7,4 & $-1,0$ \\
\hline 2007 & 63,8 & 21,1 & 30,2 & 2,0 & 15,2 & 5,4 & $-0,5$ \\
\hline 2008 & 81,0 & 32,2 & $-9,7$ & $-0,1$ & $-0,7$ & 6,5 & $-0,7$ \\
\hline 2009 & 125,9 & $-12,5$ & 20,1 & $-1,8$ & 3,0 & 11,2 & $-0,8$ \\
\hline 2010 & 139,3 & $-19,4$ & $-7,4$ & $-3,4$ & $-14,3$ & 6,7 & $-1,3$ \\
\hline 2011 & 131,0 & 20,5 & $-9,3$ & 4,6 & 15,5 & 4,0 & $-1,3$ \\
\hline
\end{tabular}

Źródło: [EUROSTAT, dostęp: 20.09.2012, 22.09.2013].

nastapił jednak spadek udziału finansowania bankowego netto w strukturze finansowania inwestycji rzeczowych, przy jednoczesnym wzroście udziału finansowania wewnętrznego (rys. 1). Warto więc zastanowić się nad przyczynami tego stanu rzeczy.

Na podstawie uzyskanych wyników można zauważyć, iż między odsetkiem wewnętrznego i bankowego finansowania zachodzi zależność korelacyjna ujemna (wraz ze wzrostem wartości finansowania wewnętrznego wartość finansowania bankowego maleje). Przyczyn należy upatrywać w kilku mechanizmach. Zgodnie z argumentacją Myersa [1984], ujętą w teorię hierarchii źródeł finansowania, w pierwszej kolejności przedsięwzięcia inwestycyjne są finansowane ze źródeł wewnętrznych, a następnie z obcych. Jak już wspomniano, w latach 1995-2010 nastapiła poprawa wyników sektora przedsiębiorstw i jego zdolności do generowania zysku z produkcji. Spadek wartości dodanej brutto transferowanej 


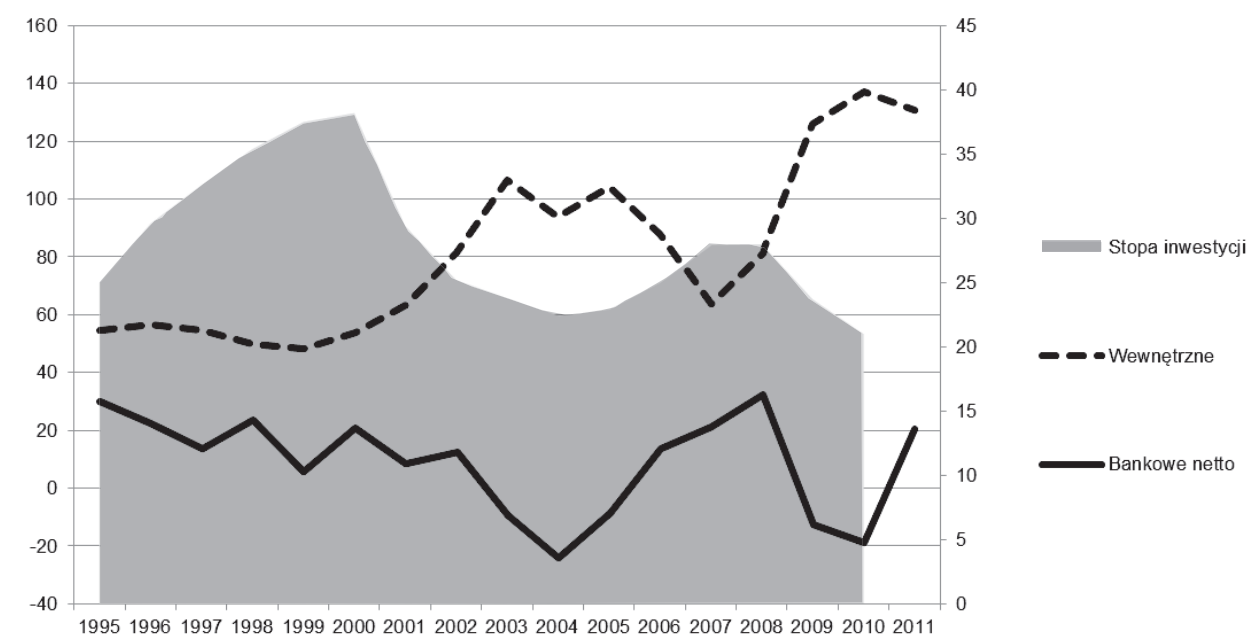

Oś lewa - wewnętrzne i bankowe źródła finansowania inwestycji rzeczowych (pkt. procentowe).

Oś prawa - stopa inwestycji brutto (pkt. procentowe).

\section{Rysunek 1}

Polski sektor przedsiębiorstw - stopa inwestycji brutto, wewnętrzne i bankowe źródła finansowania [\%]

Źródło: [EUROSTAT, dostęp: 20.08.2012, 22.09.2013]

przez sektor przedsiębiorstw do innych sektorów instytucjonalnych spowodował zwiększenie marginesu swobody w zakresie finansowania ze źródeł wewnętrznych realizowanych inwestycji rzeczowych. W analizowanym okresie w sektorze przedsiębiorstw nastapił ponadto wyraźny spadek stopy inwestycji brutto. Mniejszej aktywności inwestycyjnej w sektorze przedsiębiorstw towarzyszył więc wyraźny wzrost poprawy jego wyników. W efekcie po okresie intensywnego unowocześniania polskiej gospodarki w sektorze przedsiębiorstw wzrósł udział źródeł wewnętrznych w strukturze finansowania inwestycji rzeczowych.

Warto w tym miejscu zastanowić się także nad związkiem pomiędzy dostępnością bankowych źródeł finansowania a wartością realizowanych przez sektor przedsiębiorstw inwestycji rzeczowych. Zakładając, że poziom finansowania wewnętrznego jest stały ( $w$ określonym przedziale czasowym), a dostępność innych źródeł finansowania ograniczona, wówczas zmiany w poziomie finansowania bankowego mogą prowadzić do równoważnych zmian w poziomie realizowanych inwestycji rzeczowych, a tym samym do zmian w udziale finansowania wewnętrznego. Spadku znaczenia źródeł bankowych w strukturze finansowania inwestycji rzeczowych w sektorze przedsiębiorstw upatrywać też należy 
w skłonności sektora bankowego do pożyczania środków finansowych przedsiębiorstwom. Skłonność ta w latach 1995-2011 wyraźnie zmalała. Przyczyn należy upatrywać przede wszystkim w zniesieniu ograniczeń w ponadgranicznym przepływie kapitału oraz w nowych standardach kapitałowych w działalności bankowej. Zniesienie ograniczeń w przepływie kapitału przełożyło się na wzrost konkurencji, a nowe standardy kapitałowe do zmiany modelu biznesu, w którym to banki starały się generować dochody w formie prowizji i opłat, czyli środków niekoniecznie absorbujących nowy kapitał. Ponadto w latach 1995-2011 narastała aktywność sektora publicznego na rynku źródeł finansowania, co w konsekwencji przełożyło się na występowanie, z coraz to większym natężeniem, efektu wypychania sektora prywatnego z obiegu gospodarczego, czyli alokację części zasobów poza sektorem ściśle gospodarczym [Samborski 2013].

\section{Uwagi końcowe}

W Polsce wyznacznikiem zachodzących procesów w sferze finansowania przedsiębiorstw stały się przeobrażenia systemowe lat 90 . związane $\mathrm{z}$ transformacją gospodarki centralnie zarządzanej i przejściem do gospodarki rynkowej. Problematyki finansowania przedsiębiorstw w Polsce nie można jednak rozpatrywać w oderwaniu od procesów integracyjnych zachodzących w Europie. Jednym z filarów integracji europejskiej stała się swoboda przepływu kapitału. W konsekwencji nastapiły zmiany w modelu finansowania sektora przedsiębiorstw w Polsce. Stopniowo udział źródeł bankowych w strukturze finansowania inwestycji rzeczowych zaczął maleć. Na ten stan rzeczy wpłynęły również zmiany w strukturze oszczędności i celach inwestycyjnych gospodarstw domowych. Kluczowe znaczenie miały tutaj rozwój systemu emerytalnego i stopień polaryzacji dochodów gospodarstw domowych.

\section{Literatura}

CORBETT J., JENKINSON T.: How is investment financed? A study of Germany, Japan, the United Kingdom and the United States, The Manchester School Supplement, Blackwell Publishers Ltd., Oxford, 1997.

CORBETT J., JENKINSON T.: The financing of industry, 1970-1989: An international comparison, „Journal of the Japanese and International Economies” 1996, nr 10, s. 71-96.

EUROSTAT: Key indicators by country, http://epp.eurostat.ec.europa.eu/portal/page/portal/ sector_accounts/data/annual_dat (dostęp: 23.09.2013).

EUROSTAT: National Accounts, Poland. http://epp.eurostat.ec.europa.eu/portal/page/portal/ eurostat/home/ (dostęp: 20.08.2012). 
EUROSTAT: National Accounts, Poland, http://epp.eurostat.ec.europa.eu/portal/page/portal/ eurostat/home/ (dostęp: 22.09.2013).

GUS: Pojęcie stosowane w badaniach statystycznych statystyki publicznej, http://www.stat. gov.pl/gus/definicje_PLK_HTML.htm?id=POJ-1011.htm (dostęp: 22.09.2013).

GUS: System rachunków narodowych (SRN), Tom I, GUS, Warszawa 1996, s. 88.

HRONOVÁ S., HINDLS R.: Economic Crises in the Results of the Non-Financial Corporations Sector in the Czech Republic. „Statistika” 2012, nr 49 (3), s. 4-18.

LEYTHIENNE D., SMOKOVA T.: Business profit share and investment rate higher in the EU than in the USA, „Economy and finance. Statistics in focus” 2009, $\mathrm{nr} 28, \mathrm{~s} .1-12$.

MAYER C.: New issues in corporate finance, „European Economic Review” 1988, nr 32, S. $1167-1183$.

MAYER C.: Financial systems, corporate finance and economic development, [w:] R. Hubbard (red.), Asymmetric information, corporate finance and investment, National $\mathrm{Bu}-$ reau of Economic Research, New York 1990, s. 307-332.

MYERS S.: The capital structure puzzle, ,Journal of Finance” 1984, nr 39, s. 575-592.

SAMBORSKI A.: Finansowanie inwestycji rzeczowych $w$ warunkach gospodarki polskiej i czeskiej, [w:] J. Duraj (red.), Instrumenty ksztaltowania dochodowości i rentowności przedsiębiorstwa, „Acta Universitatis Lodziensis Folia Oeconomica” 2013, nr 278, s. 33-44.

SAMBORSKI A.: Finansowanie przedsiębiorstw poprzez emisje papierów wartościowych - diagnoza uwarunkowań i zależności, AE Katowice, Katowice 2007.

SAMBORSKI A.: Wykorzystanie rachunków narodowych $w$ analizach ekonomicznych, [w:] W. Czakon (red.), Podstawy metodologii badań w naukach o zarzadzaniu, Oficyna Wolters Kluwer Business, Warszawa 2011, s. 146-163.

\section{Significance of banks in physical investment financing. A study of Polish non-financial corporations}

\section{Abstract}

Research issues include the physical investment financing in Polish nonfinancial corporations in 1995 to 2011. The purpose of this study is to identify the structure of physical investment financing in Polish non-financial corporations, and to define the role of bank financing. The data used in the estimation of physical investment financing structure in Polish non-financial corporations, were obtained from two accounts belonging to the accumulation accounts, i.e. the capital account and the financial account. The study used net sources of finance methodology initiated by Mayer [1988, 1990], Corbett and Jenkinson [1994, 1997]. It uses the flow of funds rather than stock data. 